\title{
Comparison of Anti-Cyclic Citrullinated Peptide Antibodies Test with IgM- Rheumatoid Factor in the Diagnosis of Rheumatoid Arthritis
}

\author{
Zahra A. Hashim \\ Nawfal Y. Al-Dabbagh \\ Department of Microbiology \\ College of Medicine \\ University of Mosul
}

(Received 4/10/2011;Accepted 12/12/2011)

\begin{abstract}
Rheumatoid Factor (RF) occurs in $70-90 \%$ of patients with established rheumatoid arthritis (RA). Anti-cyclic citrullinated peptide antibody (Anti-CCP) detection can be used to diagnose RA patients with uncharacterized chronic inflammatory arthritis. The aims of the study are: 1-To measure the serum levels of anti-CCP and IgM-RF in the RA patients and the control groups. 2-To evaluate and compare these diagnostic tests in the terms of sensitivity and specificity and to determine the test which yields the best combination of sensitivity and specificity in the diagnosis of RA. 3- To assess the relationship between antiCCP antibodies test and joints deformities in comparison with IgM-RF antibodies test. Blood sample were obtained from 55 patients with established RA attending the Rheumatology Ward of Ibin-Sina Teaching Hospital during the period of $1^{\text {st }}$ November 2010 to the $1^{\text {st }}$ June 2011 and 35 apparently healthy controls. Anti-CCP antibodies and IgM-RF were measured using enzyme linked immunosorbent assay (ELISA). Patients demographic data, disease duration and joint deformities were recorded. The sensitivity and specificity of anti-CCP and IgM-RF antibodies were calculated taking the clinical diagnosis as the gold standard. Fifty five patients and 35 healthy age and sex matched controls were enrolled. Sensitivity was highest for IgM-RF test $(58.18 \%)$ followed by anti-CCP test $(56.3 \%)$. Specificity was highest for anti-CCP test $(97.14 \%)$ followed by IgM-RF test $(82.85 \%)$. A combination of the two tests improve the sensitivity and specificity for RA diagnosis to reach $59.5 \%$ and $100 \%$ respectively. Of the special diagnostic value was the detection of positive anti-CCP antibodies in $3 / 23(11.5 \%)$ of IgM-RF negative patients. Furthermore, in RA patients with hand joints deformities, anti-CCP was more often presented. The same results were obtained for IgM-RF seropositivity. The study suggests that despite lack of specificity, IgM-RF continues to be a central part of the definition of RA due to favorable sensitivity profile. Anti-CCP test is a powerful diagnostic tool of high specificity especially in RF negative RA patients. No superiority of one test over the other regarding prognosis of joint deformity was discovered.
\end{abstract}

Keywords: Rheumatoid arthritis, anti-cyclic citrullinated peptide, IgM- rheumatoid factor. 


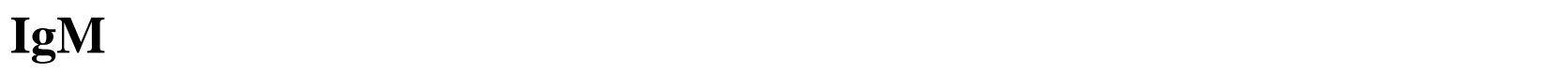 في تشخيص التهلب الفالط الرثواني}

\section{الملغ}

أهداف الدرلمة كالت: 1 - قيلس المستويت المصلية للأضداد الذاتية ضد الببتيد الحلقي المترولينيدي و العلطل الرثواني iط IgM لدى مجموعتي المرض وللسطرة. 2 - نقيم تلك الفحوصت التنخيصية لستنادا إلى الهسلسية، النوعية وإيجاد الفحص الذي يططي أعلى نتائج المسلسية والنوعية. 3 - تحديد علاقة فحص المصال

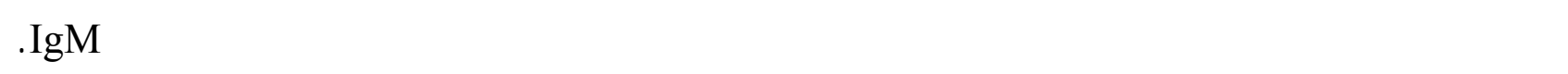

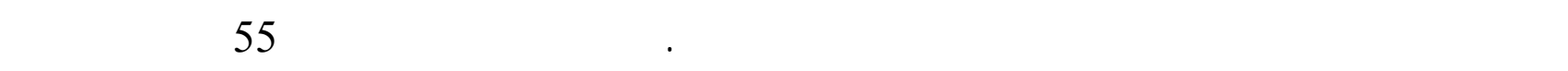

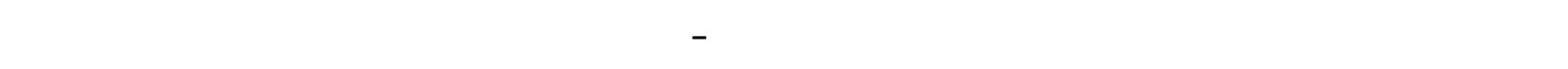
الثاني2010 لغاية الأول من حزيران 2011 و لـ ـ 35 شخصاطبيعيا. مُ قيلس الأجسلم المضادة للببتيد

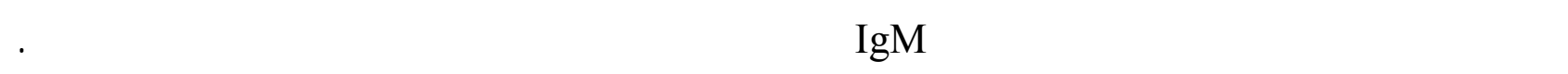
مق تسجل البيانت الديموغرافية، فترة المرض و التشوهات المفصلية للمرضف. المسلسية والنوعية لفحصي

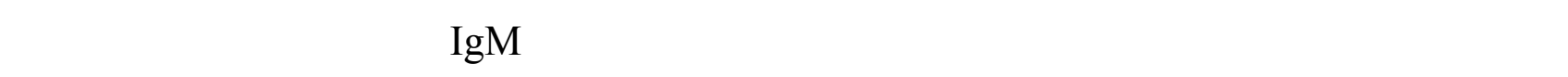

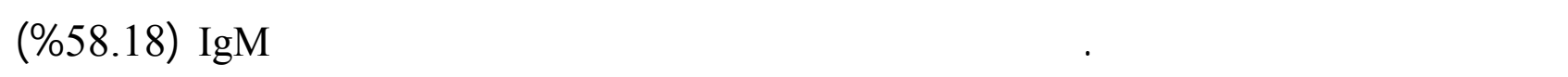

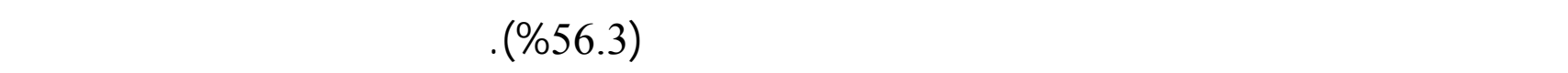

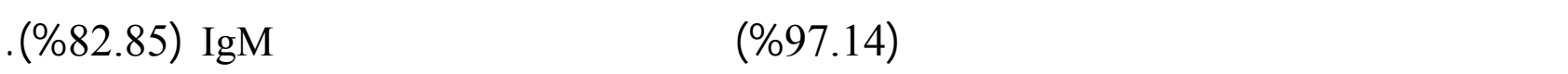

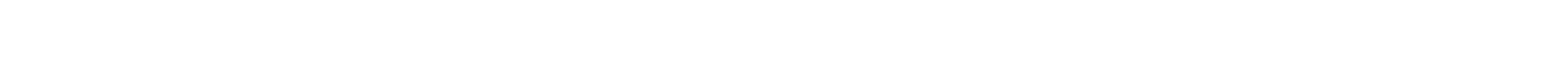
إلى 59.5\% و 100\% بالتنايع. وكان الكثف عن 23/3 (11.5\%) من المرضى اللسالبن لفحص العلمل الرثواني نهط IgM موجبين لفحص الأجسلم المضادة للببتيد الحلقي اللسترولينيدي ذي قيمة تشخيصية متميزة.

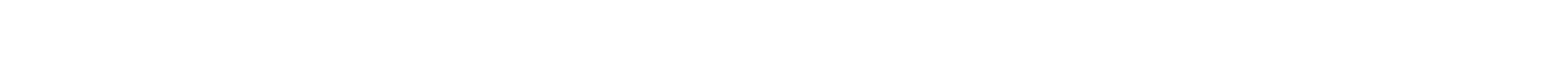

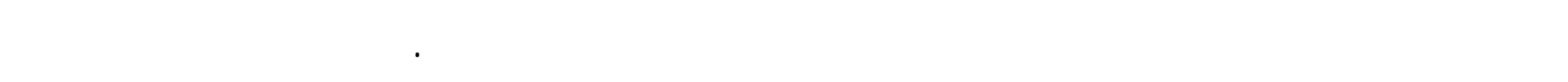

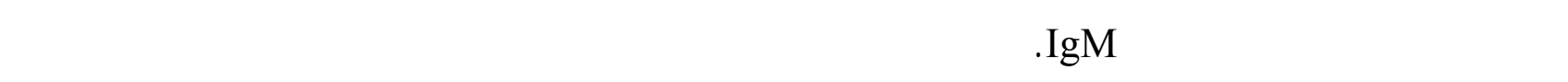

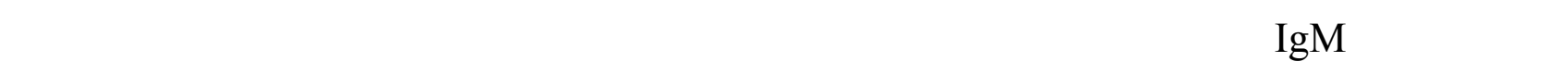

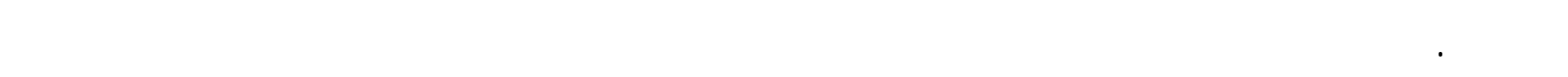

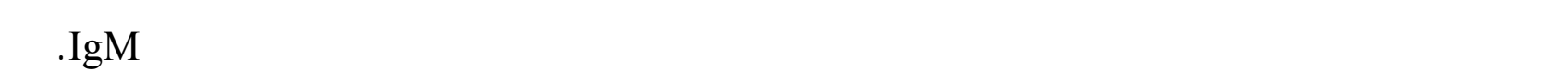

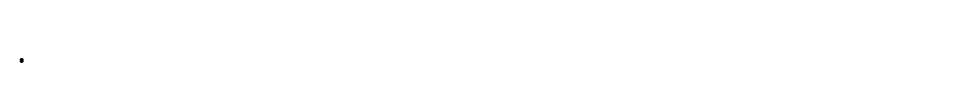

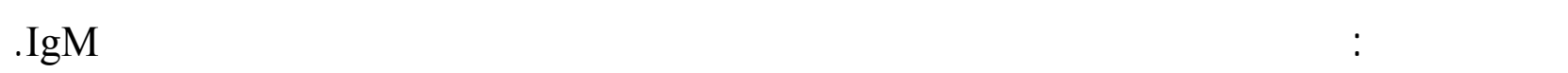




\section{INTRODUCTION}

Rheumatoid arthritis (RA) is a chronic inflammatory arthritis with the potential to cause significant morbidity and mortality. The prevalence of RA is $1 \%$ in the general population with a predilection for women ( $\mathrm{Ng}$ et al., 2006). Autoimmune diseases, such as RA are believed to develop as a result of dysregulation of the immune system, leading ultimately to RA, clinical features of which are inflammation and destruction of several joints (Arnett et al., 1988). The etiology of RA has been suggested to be a combination of genetic and environmental factors (Tobon et al., 2010). To date, it has not been possible to identify individuals at early stages of this dysregulation (i.e. before presentation of clinically obvious polyarthritis). If methods were available to predict the future development of RA, a better understanding of the events triggering the disease would be achieved, thereby creating the possibility of developing and testing preventive measures and of instituting therapy at earlier stages of disease development than is currently practiced (Berglin et al., 2004). Rheumatoid Factor (RF) is one of the criteria that proposed by the American College of Rheumatology (ACR) for diagnosis of RA. RF occurs in $70-90 \%$ of patients with established RA but population-based studies have shown much lower rates of RF positivity and it may be present in non-rheumatic conditions such as infections and even healthy individuals(Rantapää-Dahlqvist et al., 2005 and $\mathrm{Ng}$ et al., 2006).

Cyclic Citrullinated Peptide (CCP) antibodies have been described as highly specific for RA. In several studies, the diagnostic sensitivity and specificity of anti-CCP vary from $50-82 \%$ and 92.6-100\%, respectively (Serdaroğlu et al., 2008 and Vallbracht et al., 2004). The accuracy of diagnosis is important even in cases with uncharacterized chronic inflammatory arthritis; for example, a patient with lupus is treated with sulfasalazine or psoriasis arthritis with hydroxylchloroqine ( $\mathrm{Ng}$ et al., 2006). There are some studies about association of RF and anti-CCP in rheumatoid arthritis. Because of the frequency of RF and anti-CCP, antibody increases significantly over time (Rantapää-Dahlqvist et al., 2005). These studies were done on nested samples or the samples obtained years before the disease onset (Rantapää-Dahlqvist et al., 2005 and Ng et al., 2006). This study was designed to evaluate the simultaneous presence and association of these antibodies in patients with RA.

\section{MATERIALS AND METHODS}

In this case-control study, 55 RA patients recruited from Rheumatology Ward of IbinSina Teaching Hospital in Nineveh Governorate and 35 healthy age and sex matched subjects with no inflammatory, infectious or arthritic conditions were compared over a period extended from the $1^{\text {st }}$ November 2010 to the $1^{\text {st }}$ June 2011 . There were 50 females and 5 males in both case and control groups. The mean age of the patients was $47.7 \pm 10.9$ years and that of the controls was $45.2 \pm 9$ years. The mean disease duration was $7.08 \pm 6.96$ years in RA patients group.

The clinical diagnosis was made by an attending rheumatologist according to the 1987 American College of Rheumatology (ACR) revised criteria and the hand joints deformities. Anti-CCP antibodies and IgM-RF were measured in all of the patients and controls.

Anti-CCP antibodies were detected using a commercial IgG anti-CCP enzyme linked immunosorbent assay kit (Aeskulisa, Germany), following the manufacturer's instructions. Briefly, microtitre plates were incubated for 30 minutes at room temperature with serum samples diluted at 1:101 in sample buffer. Prediluted anti-CCP standards and positive and 
negative controls were added to each plate. After three washes with washing buffer solution, anti-human immunoglobulins conjugated to horseradish peroxidase (conjugate) were incubated and reacted with the antigen-antibody complex of the samples in the micrplpates. After three further washes, addition of the TMB-substrate generates an enzymatic colorimetric (blue) reaction, which was stopped by diluted acid (color change to yellow) and the plates were read at $450 \mathrm{~nm}$ (optionally) with automated device within 30 minutes. AntiCCP were considered positive when the absorbance value was higher than the cut-off of the kit $(18 \mathrm{U} / \mathrm{ml})$. The rate color formation from the chromogen is a function of the amount of conjugate bound to the antigen-antibody complex and this is proportional to the initial concentration of the respective antibodies in the patient sample.

IgM-Rheumatoid Factor was detected by ELISA kit (DRG instruments $\mathrm{GmbH}$, Germany). Fc fragments of highly purified human immunoglobulin $G$ is bound to microwells. Antibodies against this antigen, if present in diluted serum, bind to the respective antigen. The microwells were washed and the unspecific serum components and unbound serum antibodies were removed. Horseradish peroxidase (HRP) conjugated antihuman IgM immunologically detected the bound patient antibodies forming a conjugate/antibody/antigen complex. The microwells were washed and the unbound conjugate were removed. An enzyme substrate in the presence of bound conjugate hydrolyzed to form a blue color. The addition of an acid stopped the reaction forming a yellow end-product. The intensity of this yellow color is measured photo-metrically at 450 $\mathrm{nm}$ and is directly proportional to the concentration of IgM antibodies present in the original sample and a level above $20 \mathrm{U} / \mathrm{ml}$ is considered positive.

Statistical analysis was performed as follow :

Sensitivity $=[$ true positive/(true positive + false negative $)] * 100$

Specificity $=[$ true negative $/($ true negative + false positive $)] * 100$

Positive predictive value $=[\text { true positive }(\text { true positive }+ \text { false positive })]^{*} 100$

Negative predictive value $=[$ true negative (true negative + false negative $)]^{*} 100$

Accuracy rate $=[(\text { true positive }+ \text { true negative }) /(\text { total positives }+ \text { total negatives })]^{* 100}$

Odd ratio $=[($ true positive/false negative $) /($ false positive/true negative $)]$

All data were expressed in mean $\pm \mathrm{SD}$ and the groups means were compared by unpaired t-test.

\section{RESULTS}

The resulted sensitivity, specificity, PPV, NPV, 95\% confidence interval (CI), odd ratio (OR) and accuracy rate considered for anti-CCP and IgM-RF are shown in Tables 1 and 2.

Anti-CCP test demonstrated the highest specificity followed by IgM-RF, however the highest sensitivity was demonstrated with IgM-RF followed by anti-CCP. The sensitivity and specificity of the combination of anti-CCP and IgM-RF tests were $59.5 \%$ and $100 \%$ respectively. Combination of anti-CCP and IgM-RF in the diagnosis of RA resulted in the highest sensitivity and specificity as demonstrated in Table1(c). The PPV, NPV and accuracy rate of anti-CCP plus IgM-RF were $100 \%, 59.5 \%$ and $74.6 \%$ respectively as shown in Table 3. 
Anti-CCP was detected in $31 / 55(56.36 \%)$ of the RA patients involved in this study and in $1 / 35(2.85 \%)$ of the controls with a significant difference between the two groups $(\mathrm{p}=$ $0.04)$. The mean concentration \pm SD was $195.63 \pm 126.57 \mathrm{U} / \mathrm{ml}$ and the values ranged from 19.5-432.3 U/ml. IgM- rheumatoid factor detected by ELISA test was found in 32/55 (58.18\%) RA patients and among 6/35 (17.5\%) of the controls with a highly significant difference between the two groups $(\mathrm{p}=0.009)$. The mean $\pm \mathrm{SD}$ of IgM-RF in RA patients was $310 \pm 233.25 \mathrm{U} / \mathrm{ml}$ as shown in Table 4 .

In addition, the study showed that 28/31 (90.3\%) of the anti-CCP positive patients were positive for IgM-RF. However, no positive result was noted among the controls for both anti-CCP and RF. $3 / 23$ (11.5\%) of IgM-RF negative patients were anti-CCP positive as illustrated in Table 5.

Data presented in Table 6 showed that significant differences were noted between seropositive and seronegative patients (both for anti-CCP and RF) in regard to the age, disease duration and joint deformity $(p \leq 0.05)$. Moreover, a higher prevalence of anti-CCP positive results was found among patients with hand joints deformities than in patients with no deformities ( $60 \%$ vs. $40 \%$ respectively) and the difference was significant $(p=0.04)$. The concentration of anti-CCP was higher among patients with the deformity than among patients with no deformity (mean concentration $249.4 \mathrm{U} / \mathrm{ml}$ vs. $173.5 \mathrm{U} / \mathrm{ml}$ respectively, $\mathrm{p}=$ 0.03) Figure 1. Similar results were obtained for RF seropositivity (Table 6) with a mean concentration difference of $417.48 \mathrm{U} / \mathrm{ml}$ vs. $252 \mathrm{U} / \mathrm{ml}$; patients with deformity vs. patients with no deformity, $\mathrm{p}=0.02$ ) as shown in Figure 2.

The patients in the current study were categorized according to the type of therapy used as follow (Table 7 and 8):

Four patients $(7.27 \%)$ had no treatment; of them, only one patient was anti-CCP and IgM-RF positive with a titer of 143.2 and $20.8 \mathrm{U} / \mathrm{ml}$ respectively.

Patients received NSAID only but no MTX or steroid were $11(20 \%)$; of them, 4 cases were anti-CCP and IgM-RF positive and two had joints deformities. Two other cases had joints deformities but were anti-CCP and RF negative. These two cases had disease duration of 8 and 10 years and a titer of anti-CCP of 358.3 and $310.9 \mathrm{U} / \mathrm{ml}$ respectively and a titer of RF of 564.4 and $590 \mathrm{U} / \mathrm{ml}$ respectively.

Patients received MTX alone were $10(18.18 \%)$; six out of them were anti-CCP positive and had a relatively decreased level of anti-CCP compared to other category and three of them were RF positive. One case was RF positive and anti-CCP negative. Two cases had joints deformities but were anti-CCP and RF negative.

Patients received oral steroid alone were $6(10.9 \%)$. Half the cases (three) were antiCCP and RF positive and received oral steroid for more than 6 months. Three cases had steroid for less than 6 months, one case was anti-CCP positive only and one case was antiCCP and RF positive.

Patients received MTX with steroid and NSAID were 18 (32.72\%). Eleven patients were anti-CCP and RF positive. Four patients had joints deformities, one of them was seronegative for both anti-CCP and RF. About half of the positive cases had a decreased titer of anti-CCP and RF compared with other treatment category.

Patients received MTX with other DMARD (chloroquine or sulfasalazine) were four cases $(7.27 \%)$ and received this combined therapies for long periods. Three out of these four cases were anti-CCP and RF positive and two of them had joints deformities. 
Two cases (3.63\%) received the second line DMARD (sulfasalazine) with steroid. The two cases were anti-CCP and RF positive and one of them had joints deformities.

Table 1: Sensitivity and specificity of anti-CCP test.

\begin{tabular}{|l|l|l|l|l|}
\hline \multirow{2}{*}{} & \multicolumn{5}{|c|}{ RA (patients + control) } \\
\hline \multirow{3}{*}{ Anti-CCP } & & + & - & total \\
\cline { 2 - 5 } & + & 31 & 1 & 32 \\
\cline { 2 - 5 } & - & 24 & 34 & 58 \\
\cline { 2 - 5 } & total & 55 & 35 & 90 \\
\hline
\end{tabular}

Sensitivity of anti-CCP $=31 /(31+24) \times 100=56.3 \%$

Specificity of anti-CCP $=34 /(34+1) \times 100=97.14 \%$

$\mathrm{PPV}=31 / 32=96.87 \%, \mathrm{NPV}=34 / 58=58.62 \%, \mathrm{OR}=43.91,95 \% \mathrm{CI}=33.32-45.6$, Accuracy rate $=72.22 \%$

Table 2: Sensitivity and specificity of IgM-RF.

\begin{tabular}{|l|l|l|l|l|}
\hline & \multicolumn{4}{|c|}{ RA (patients + control) } \\
\hline \multirow{3}{*}{ IgM-RF } & & + & - & total \\
\cline { 2 - 5 } & + & 32 & 6 & 38 \\
\cline { 2 - 5 } & - & 23 & 29 & 52 \\
\cline { 2 - 5 } & total & 55 & 35 & 90 \\
\hline
\end{tabular}

Sensitivity of IgM-RF $=32 /(32+23) \times 100=58.18 \%$

Specificity of $\mathrm{IgM}-\mathrm{RF}=29 /(29+6) \times 100=82.85 \%$ $\mathrm{PPV}=32 / 38=84.21 \%, \mathrm{NPV}=29 / 52=55.67 \%, \mathrm{OR}=6.724,95 \% \mathrm{CI}=4.35-10.32$, Accuracy rate $=67.7 \%$.

Table 3: Sensitivity and Specificity of anti-CCP + IgM-RF tests.

\begin{tabular}{|c|c|c|c|c|}
\hline & \multicolumn{4}{|c|}{ RA (patients + control) } \\
\hline \multirow{4}{*}{$\begin{array}{c}\text { Anti-CCP } \\
+ \\
\text { IgM-RF }\end{array}$} & & + & - & total \\
\hline & + & 28 & 0 & 28 \\
\hline & - & 19 & 28 & 47 \\
\hline & total & 47 & 28 & 75 \\
\hline
\end{tabular}

Sensitivity of anti-CCP + IgM-RF $=28 / 47 \times 100=59.5 \%$

Specificity of anti-CCP + IgM-RF $=28 / 28 \times 100=100 \%$

$\mathrm{PPV}=28 / 28 \times 100=100 \%, \mathrm{NPV}=28 / 47 \times 100=59.5 \%$, Accuracy rate $=74.6 \%$. 
Table 4: Laboratory characteristics of the RA patients and controls

\begin{tabular}{|c|c|c|c|c|c|c|c|}
\hline Parameter & $\begin{array}{c}\text { Case } \\
\text { No. }\end{array}$ & $\%$ & M \pm SD & $\begin{array}{c}\text { Control } \\
\text { No. }\end{array}$ & \% & M \pm SD & p-value \\
\hline Anti-CCP & 31 & $\begin{array}{c}31 / 55 \\
56.36\end{array}$ & $195.63 \pm 126.57$ & 1 & $\begin{array}{c}1 / 35 \\
2.85\end{array}$ & 18.2 & $0.04^{*}$ \\
\hline IgM-RF & 32 & $\begin{array}{c}32 / 55 \\
58.18\end{array}$ & $310 \pm 233.25$ & 6 & $\begin{array}{c}6 / 35 \\
17.5\end{array}$ & $\begin{array}{c}44 \\
\pm 43.2\end{array}$ & $0.009 *$ \\
\hline
\end{tabular}

Table 5: Comparison of anti-CCP and RF reactivity.

\begin{tabular}{|c|c|c|c|c|}
\hline \multicolumn{5}{|c|}{55 RA patients } \\
\hline \multicolumn{2}{|c|}{$\begin{array}{c}\text { Anti-CCP (+) } \\
\quad \mathbf{N}=31\end{array}$} & \multicolumn{2}{|c|}{$\begin{array}{c}\text { Anti-CCP (-) } \\
N=24\end{array}$} & Total \\
\hline IgM-RF (+) & $\mathrm{N}=28(90.32 \%)$ & IgM-RF (+) & $\mathrm{N}=4(16.6 \%)$ & 32 \\
\hline IgM-RF (-) & $\mathrm{N}=3(9.67 \%)$ & IgM-RF (-) & $\mathrm{N}=20(83.3 \%)$ & 23 \\
\hline \multicolumn{5}{|c|}{35 controls } \\
\hline \multicolumn{2}{|c|}{$\begin{array}{c}\text { Anti-CCP (+) } \\
\mathbf{N}=1\end{array}$} & \multicolumn{2}{|c|}{$\begin{array}{c}\text { Anti-CCP (-) } \\
\mathrm{N}=34\end{array}$} & Total \\
\hline IgM-RF (+) & $\mathrm{N}=0$ & IgM-RF (+) & $\mathrm{N}=6$ & 6 \\
\hline IgM-RF (-) & $\mathrm{N}=1$ & IgM-RF (-) & $\mathrm{N}=28$ & 29 \\
\hline
\end{tabular}

Table 6: Comparison of the characteristics of patients with or without RF and anti-CCP antibodies.

\begin{tabular}{|l|c|c|c|c|c|c|}
\hline & RF + & RF- & p-value & Anti-CCP+ & Anti-CCP - & p-value \\
\hline Number of cases & 32 & 23 & 0.32 & 31 & 24 & 0.31 \\
\hline Age & $50.84 \pm 11.03$ & $43.3 \pm 9.2$ & $0.00^{*}$ & $50.22 \pm 10.64$ & $44.4 \pm 10.50$ & $0.000^{*}$ \\
\hline Disease duration & $9.45 \pm 7.6$ & $3.78 \pm 4.24$ & $0.001^{*}$ & $9.27 \pm 7.44$ & $4.25 \pm 5.17$ & $0.001^{*}$ \\
\hline $\begin{array}{l}\text { Joints deformities } \\
(\%)\end{array}$ & $9 / 15(60 \%)$ & $6 / 15(40 \%)$ & $0.04^{*}$ & $9 / 15(60 \%)$ & $6 / 15(40 \%)$ & $0.04 *$ \\
\hline *p-value $\leq 0.05$ was considered significant &
\end{tabular}


Table 7: The prevalence of patients using different treatments

\begin{tabular}{|c|c|c|}
\hline Therapy & No. of patients & Percentage \\
\hline No therapy & 4 & $7.27 \%$ \\
\hline NSAIDs only & 11 & $20 \%$ \\
\hline MTX only & 10 & $18.18 \%$ \\
\hline Oral steroid only & 6 & $10.9 \%$ \\
\hline Oral steroid+MTX+NSAID & 18 & $32.72 \%$ \\
\hline MTX + other DMARD & 4 & $7.27 \%$ \\
\hline Sulfasalazine+oral steroid & 2 & $3.63 \%$ \\
\hline Total & 55 & $100 \%$ \\
\hline
\end{tabular}

Table 8: Treatment pattern and autoantibodies status.

\begin{tabular}{|c|c|c|c|c|c|}
\hline \multicolumn{6}{|c|}{ No therapy } \\
\hline \multirow{2}{*}{$\begin{array}{l}\text { Case no. } \\
\text { Total }=4 \text { cases }\end{array}$} & \multirow{2}{*}{$\begin{array}{c}\text { Duration } \\
\text { of disease } \\
\text { (y) }\end{array}$} & \multicolumn{2}{|c|}{ Anti-CCP } & IgM-RF & \multirow{2}{*}{$\begin{array}{c}\text { Joints } \\
\text { Deformities }\end{array}$} \\
\hline & & & Titer & Titer & \\
\hline Case no.1 & 1 & \multicolumn{2}{|l|}{-} & - & Mild \\
\hline Case no. 2 & 1 & \multicolumn{2}{|l|}{-} & - & No \\
\hline Case no. 3 & 5 & + & 143.2 & 20.8 & No \\
\hline Case no.4 & 6 & \multicolumn{2}{|l|}{-} & - & No \\
\hline \multicolumn{6}{|c|}{ NSAID alone on need (no MTX or steroid) } \\
\hline \multirow{2}{*}{$\begin{array}{l}\text { Case no. } \\
\text { (Total=11 cases) }\end{array}$} & \multirow{2}{*}{$\begin{array}{c}\text { Duration } \\
\text { of disease } \\
\text { (y) }\end{array}$} & \multicolumn{2}{|c|}{ Anti-CCP } & IgM-RF & \multirow{2}{*}{$\begin{array}{c}\text { Joints } \\
\text { Deformities }\end{array}$} \\
\hline & & $+/-$ & Titer & $+/-\quad$ Titer & \\
\hline Case no.1 & 1 & \multicolumn{2}{|l|}{-} & - & No \\
\hline Case no. 2 & 10 & \multicolumn{2}{|l|}{-} & - & Mild \\
\hline Case no. 3 & 1.5 & \multicolumn{2}{|r|}{19.53} & +212.5 & $\mathrm{No}$ \\
\hline Case no. 4 & 10 & \multicolumn{2}{|c|}{$+\quad 310.9$} & $+\quad 590$ & Severe \\
\hline Case no. 5 & 1 & \multicolumn{2}{|l|}{-} & - & No \\
\hline Case no.6 & 18 & \multicolumn{2}{|l|}{-} & - & No \\
\hline Case no. 7 & 2 & \multicolumn{2}{|l|}{-} & - & $\mathrm{No}$ \\
\hline Case no. 8 & 8 & & 358.3 & +564.4 & Mild \\
\hline Case no.9 & 1 & - & & - & $\mathrm{No}$ \\
\hline Case no. 10 & 1 & + & 233.5 & +611.3 & $\mathrm{No}$ \\
\hline Case no.11 & 1 & - & & - & Severe \\
\hline & & MT & $\mathrm{X}$ alone & & \\
\hline Case no. & Duration & Ant & $\mathrm{CCP}$ & IgM-RF & Joints \\
\hline ( Total $=10$ cases) & $\begin{array}{l}\text { of } \\
\text { treatment }\end{array}$ & & Titer & $+/-\quad$ Titer & Deformities \\
\hline Case no.1 & & + & 116 & 290 & No \\
\hline Case no. 2 & $<6 \mathrm{~m}$ & & 381.5 & 415 & $\mathrm{No}$ \\
\hline Case no. 3 & & + & 18.5 & - & No \\
\hline Case no. 4 & & & 204.6 & 465.5 & No \\
\hline & & & & & Cont.../ \\
\hline
\end{tabular}




\begin{tabular}{|c|c|c|c|c|}
\hline Case no. 5 & \multirow{6}{*}{$>6 \mathrm{~m}$} & - & - & Severe \\
\hline Case no. 6 & & - & 20.5 & No \\
\hline Case no.7 & & 18.5 & - & $\mathrm{No}$ \\
\hline Case no. 8 & & $+\quad 46.03$ & - & No \\
\hline Case no. 9 & & - & - & Moderate \\
\hline Case no. 10 & & - & - & No \\
\hline \multicolumn{5}{|c|}{ Steroid alone } \\
\hline $\begin{array}{l}\text { Case no. } \\
\text { (Total }=6 \text { cases) }\end{array}$ & $\begin{array}{c}\text { Durationof } \\
\text { treatment }\end{array}$ & $\begin{array}{l}\text { Anti-CCP } \\
+/- \\
\text { Titer }\end{array}$ & $\begin{array}{c}\text { IgM-RF } \\
+/- \\
\text { Titer }\end{array}$ & $\begin{array}{c}\text { Joints } \\
\text { Deformities }\end{array}$ \\
\hline Case no.1 & \multirow[t]{3}{*}{$<6 \mathrm{~m}$} & $+\quad 368.8$ & 492.5 & No \\
\hline Case no. 2 & & - & $+\quad 612.76$ & No \\
\hline Case no. 3 & & - & - & No \\
\hline Case no. 4 & \multirow{3}{*}{$>6 \mathrm{~m}$} & 202.6 & 448 & Moderate \\
\hline Case no.5 & & 351.9 & 38 & $\mathrm{No}$ \\
\hline Case no.6 & & 299.3 & 137.5 & No \\
\hline \multicolumn{5}{|c|}{ MTX + Steroid + NSAID } \\
\hline $\begin{array}{l}\text { Case no. } \\
\text { (Total }=18 \text { cases })\end{array}$ & $\begin{array}{l}\text { Duration of } \\
\text { treatment }\end{array}$ & $\begin{array}{l}\text { Anti-CCP } \\
+/- \\
\text { Titer }\end{array}$ & $\begin{array}{l}\text { IgM-RF } \\
+/- \\
\text { Titer }\end{array}$ & $\begin{array}{c}\text { Joints } \\
\text { Deformities }\end{array}$ \\
\hline Case no.1 & \multirow{7}{*}{$<6 \mathrm{~m}$} & $\begin{array}{l}+432.3 \\
\end{array}$ & $+\quad 591.7$ & No \\
\hline Case no. 2 & & - & - & No \\
\hline Case no. 3 & & - & - & No \\
\hline Case no. 4 & & - & 30 & No \\
\hline Case no.5 & & 154.7 & 338 & No \\
\hline Case no.6 & & 219 & 30 & No \\
\hline Case no. 7 & & - & - & No \\
\hline Case no. 8 & \multirow{11}{*}{$>6 \mathrm{~m}$} & 68.82 & 42.5 & No \\
\hline Case no.9 & & 50.6 & 24 & No \\
\hline Case no.10 & & 362.9 & 590 & No \\
\hline Case no.11 & & - & - & No \\
\hline Case no.12 & & 315.4 & 224 & Severe \\
\hline Case no.13 & & 288.2 & 262 & Severe \\
\hline Case no.14 & & $+\quad 235.2$ & 35 & Severe \\
\hline Case no. 15 & & - & - & No \\
\hline Case no.16 & & 74.88 & 28.75 & No \\
\hline Case no.17 & & $+\quad 82.37$ & 36.25 & No \\
\hline Case no.18 & & - & - & Mild \\
\hline \multicolumn{5}{|c|}{ MTX + other DMARD } \\
\hline $\begin{array}{l}\text { Case no. } \\
\text { (Total }=4 \text { cases })\end{array}$ & $\begin{array}{l}\text { Duration of } \\
\text { treatment }\end{array}$ & $\begin{array}{l}\text { Anti-CCP } \\
+/- \\
\text { Titer } \\
\end{array}$ & $\begin{aligned} & \text { IgM-RF } \\
&+/- \\
& \text { Titer }\end{aligned}$ & $\begin{array}{c}\text { Joints } \\
\text { Deformities }\end{array}$ \\
\hline
\end{tabular}




\begin{tabular}{|c|c|c|c|c|}
\hline Case no. 1 & $>6 \mathrm{~m}$ & - & - & No \\
\hline Case no. 2 & $7 y$ & 192.6 & 565.5 & Severe \\
\hline Case no. 3 & $6 y$ & 164 & 337.5 & No \\
\hline Case no. 4 & $4 y$ & 181.3 & 541.8 & Severe \\
\hline \multicolumn{5}{|c|}{ Sulfasalazine +Steroid } \\
\hline \multirow{2}{*}{$\begin{array}{c}\text { Case no. } \\
(\text { Total=2cases })\end{array}$} & \multirow{2}{*}{$\begin{array}{c}\text { Duration of } \\
\text { treatment }\end{array}$} & Anti-CCP & IgM-RF & Joints \\
\hline & & Titer & Titer & Deformities \\
\hline Case no.1 & $>6 \mathrm{~m}$ & 166.5 & 526.7 & Severe \\
\hline Case no.2 & $>6 \mathrm{~m}$ & 18.5 & 624 & No \\
\hline
\end{tabular}

$\mathrm{m}=$ month, $\mathrm{y}=$ year, $\mathrm{MTX}=$ methotrexate, $\mathrm{NSAID}=$ non steroidal anti-inflammatory drug

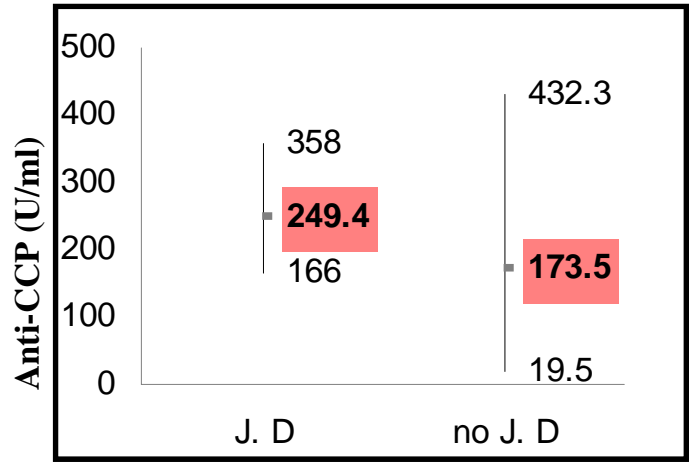

Fig.1: Anti-CCP titer in patients with or without deformity

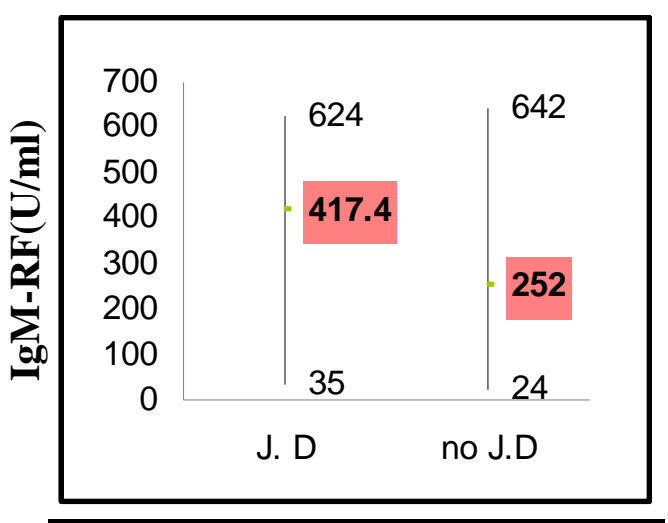

Fig. 2: IgM-RF titer in patients with or without deformity

$$
\begin{gathered}
\mathrm{J} . \mathrm{D}=\text { Joint deformity } \\
=\text { mean titer }
\end{gathered}
$$

\section{DISCUSSION}

For the 55 RA patients included in this study, the specificity obtained for anti-CCP test (97.14\%) is comparable to those obtained by other studies (Serdaroğlu et al., 2008; AgyeiFrempong et al., 2010 and Zeng et al., 2003) which reported a specificity of 97\% , 96.69\% and $100 \%$ respectively. In comparison with the IgM-RF, the obtained specificity of anti-CCP was higher than that for IgM-RF $(82,85 \%)$. This result is consistent with previous studies (Dubucquoi et al., 2003; Tofiq 2007 and Agyei-Frempong et al., 2010). The accuracy rate of anti-CCP test is $72.22 \%$ which is higher than that of IgM-RF (67.7\%). These results mean that anti-CCP test is more reliable in detecting RA than RF even in old cases, because some time patients with lupus or psoriasis is treated as RA for several years $(\mathrm{Ng}$ et al., 2006). The OR resulted in our study regarding anti-CCP for developing RA was 43.91 while for IgM-RF was 6.72. This result is in agreement with studies of other investigators (Rantapää-Dahlqvist et al., 2003 and Berglin et al., 2004) while in contrast to other study (Mobini et al., 2010) in which the OR for RF was higher than for anti-CCP. In contrast, only one study (Hodkinson et al., 2007) showed a higher specificity of RF (90.7\%) than antiCCP $(84.9 \%)$ and almost equal sensitivity for both tests. The sensitivity of anti-CCP test obtained by this study $(56.3 \%)$, however; did not differ significantly from that of IgM-RF $(58.18 \%)$. Although there is some consensus from various studies in the literature about 
specificity, there are variation in diagnostic sensitivity ranging from $64 \%-89 \%$ (Serdaroğlu et al., 2008). These variation can be due to different cut-off value, difference in serum dilution or difference in detection technique (Agyei-Frempong et al., 2008). Our data revealed that the combined measurement of both anti-CCP and IgM-RF antibodies resulted in improved specificity (100\%) and sensitivity (59.5\%), also PPV and accuracy rate were higher (100\% and $74.6 \%$ respectively) than for testing of either auto-antibody alone. These results are in accordance with results obtained by several studies (Hodkinson et al., 2007; Agyei-Frempong et al., 2008; Mobini et al., 2010). The low sensitivity of anti-CCP test indicates that a negative anti-CCP antibodies does not exclude the disease, but its high specificity means that a positive result increase the probability that the patient will have RA.

The prevalence of anti-CCP antibodies and IgM-RF were $56.36 \%$ and $58.18 \%$ of RA patients respectively and their prevalence in the control group were $2.85 \%$ and $17.5 \%$ respectively with a significant difference between the two groups $(p<0.05)$. This result demonstrates the value of anti-CCP and IgM-RF antibodies in predicting the presence of RA which is in agreement with previous studies (Nell et al., 2004 and Serdaroğlu et al., 2008).

Our study revealed that $11.5 \%$ of IgM-RF negative patients were tested positive for anti-CCP antibodies. The positive anti-CCP results especially in seronegative RA patients strongly support the diagnosis of RA serologically. This result is comparable to the previous studies(Vallbracht et al., 2004; Mobini et al., 2010; Fathi et al., 2008). It was also noted that both anti-CCP and IgM-RF were negative in $36.4 \%$ of the patients involved in this study, comparably, a previous study by Inanc and Colleagues (2007) demonstrated that $30 \%$ of RA patients were negative for the two tests. This suggest that a still unknown etiopathological events associated with the development of RA.

Our study also assessed both anti-CCP positivity and titer in patients with or without joint deformity and it was found that the frequency of positive anti-CCP result was higher in patients with deformity than those with no deformity ( $60 \%$ vs. $40 \%$ respectively). The mean anti-CCP concentration was higher among patients with deformity than those with no deformity $(249.4 \mathrm{U} / \mathrm{ml}$ vs. $173.5 \mathrm{U} / \mathrm{ml}$ respectively). These results are in accordance to numerous studies(Van Gaalen et al., 2005; Meyer et al., 2006 and Inanc et al., 2007). Another study (Berglin et al., 2006), also, found that anti-CCP concentration, beyond positivity, was indicative of more aggressive radiographic progression and worse disease severity. Only one study (Lee et al., 2009) failed to show such an association but found overlapping levels in these patients population. Since an association between erosion/deformity and RF positivity had been appreciated in some studies (Bas et al., 2000 and Inanc et al., 2007) and not in others (Del Val del Amo et al., 2006 and Meyer et al., 2006) we further investigated this association and found comparable results to those obtained for anti-CCP positivity. Also, as with anti-CCP titer, there was a significant difference in the mean RF concentration between the two groups $(417.4 \mathrm{U} / \mathrm{ml}$ vs. $252 \mathrm{U} / \mathrm{ml}$, patients with deformity vs. patients without deformity) and this is also in accordance to one study (Miriovsky et al., 2010) but in contrast to other study (Lee et al., 2009) which found no difference. These autoantibodies association with clinical signs of joints deformity suggests their potential usefulness as markers of prognosis. Our analyses did not reveal predictive superiority of one autoantibody over the other, contrary to previous reports 
suggesting that anti-CCP is a stronger predictor than RF in outcomes such as radiographic changes(Forslind et al., 2004 and Kastbom et al., 2004).

The current study did not examine the associations of autoantibodies concentrations with treatment responses to specific therapeutic agents given the heterogeneity in treatments received and lack of follow-up of patients agreeing with other studies e.g. (Lee et al., 2009 and Miriovsky et al., 2010). However, four patients in the present study were found to have no therapy and only one of them was anti-CCP positive. In addition, only $4 / 11$ patients receiving simple analgesic were anti-CCP positive. This mean that anti-CCP negative patients might have a lower disease activity/severity which did not intend the use of aggressive therapy as theses patients did not receive any DMARD. This correlate with finding that anti-CCP positive patients had more aggressive disease state forcing the commence of effective treatment (Syversen et al., 2008 and Miriovsky et al., 2010).

In the other hand, 6/10 patients receiving MTX alone were anti-CCP positive. Eleven out of the 18 cases receiving MTX plus steroid were anti-CCP positive and three out of 4 cases receiving MTX plus other DMARD were also anti-CCP positive. This meant that 20/32 cases receiving MTX (with or without other treatment) were anti-CCP positive. This is in accordance with finding of Mobini and his team (2010) who stated that anti-CCP positive group was more highly associated with more MTX use but in contrast to the study of Bas and Colleagues (2003) who found no difference. A decreased anti-CCP titer could be seen in patients treated with MTX, yet; this required further clarification. However, Spadaro and Riccieri (2005) showed that after 6 months of MTX treatment, anti-CCP antibody levels were not modified. Anti-CCP positive patients, more often than not, remain positive despite treatment (Niewold et al., 2007). It was also found in the current study that despite having a negative anti-CCP assay and receiving MTX therapy, a number of patients had an active disease state and developed mild joints deformities. This might indicate that MTX had a lower effect on anti-CCP negative patients and might suggest that anti-CCP negative RA is a different disease entity. Van Dongen and Colleagues (2007) found that the beneficial outcomes of MTX in patients with probable RA were most pronounced in patients with anti-CCP. In striking contrast, in the anti-CCP negative subgroup, the effect of MTX on the development of RA, the radiographic progression, and even on the signs and symptoms, was not demonstrable. Finally, it was found that the presence of patients treated with MTX but had joints deformities might required the use of combined therapy of MTX with other biological agent (Emery et al., 2008).

\section{CONCLUSIONS}

In clinical practice, both IgM-RF and anti-CCP tests may be useful, IgM-RF for their good sensitivity and as a marker of disease severity and anti-CCP for their high specificity and their presence in some RF-negative RA patients. No predictive superiority of one autoantibody over the other in regard to radio-graphical changes were observed and the IgM-RF is still mostly used as a screening marker in the diagnosis of RA.

\section{ACKNOWLEDGEMENTS}

We are grateful to Dr. Wameedh Al-Emarry/Consultant Rheumatologist and to Prof. Dr. Zainalabideen A. Abdullah for their help and encouragement in dealing with this subject. We are also grateful to Ibn-Sina Teaching Hospital medical staff and sub-staff for 
their help and to Dr. Saad Al-Husaini who performed the physical examination of the patients.

\section{REFERENCES}

Agyei-Frempong, M.T.; Sakyi, S. A.; Quansah, R. E. (2010). Comparison of anti-CCP peptide with rheumatoid factor and its isotypes for early differential diagnosis and prognosis of rheumatoid arthritis. J. Med. Sci.,10(1), 19-24.

Arnett, F.C.; Edworthy, S.M.; Bloch, D.A.; McShane, D.J.; Fries, J.F.; Cooper, N.S.; Healey, L.A.; Kaplan, S.R.; Liang, M.H.; Luthra, H.S. (1988). The american rheumatism association 1987 revised criteria for the classification of rheumatoid arthritis. Arthritis. Rheum., 31, 315-324.

Bas, S.; Genevay, S.; Meyer, O.; Gabay, C. (2003). Anti-cyclic citrullinated peptide antibodies, $\operatorname{IgM}$ and $\operatorname{IgA}$ rheumatoid factors in the diagnosis and prognosis of rheumatoid arthritis. Oxford J. Rheumatol., 42, 677-680.

Bas, S.; Perneger, T.V.; Mikhnevitch, E.; Seitz, M.; Tiercy, J.M.; Roux-Lombard, P.; Guerne, P.A. (2000). Association of rheumatoid factors and anti-filaggrin antibodies with severity of erosions in rheumatoid arthritis. Oxford J. Rheumatol., 39, 10821088.

Berglin, E.; Johansson, T.; Sundin, U.; Jidell, E.; Wadell, G.; Hallmans, G.; RantapääDahlqvist, S.(2006). Radiological outcome in rheumatoid arthritis is predicted by presence of antibodies against cyclic citrullinated peptide before and at disease onset, and by IgA-RF at disease onset. Ann. Rheum. Dis., 65, 453-458.

Berglin, E.; Padyukov, L.; Sundin, U.; Hallmans, G.; Stenlund, H.; Van Venrooij, W.J.; Klareskog, L.; Dahlqvist, S.R.(2004). A combination of autoantibodies to cyclic citrullinated peptide (CCP) and HLA-DRB1 locus antigens is strongly associated with future onset of rheumatoid arthritis. Arthritis Res. Ther., 6(4), 303-308.

Del Val del Amo, N.; Bosch, I.R.; Manteca, F.C.; Polo, G. R.; Cortina, L.E. (2006). Anticyclic citrullinated peptide antibody in rheumatoid arthritis: relation with disease aggressiveness. Clin. Exp. Rheumatol.,24(3), 281-286.

Dubucquoi, S.; Solau-Gervais, E.; Lefranc, D.; L Marguerie, L.; Sibilia, J.; J Goetz, J.; Dutoit, V.; Fauchais, A.; Hachulla,E.; Flipo,R.; Prin, L.(2004). Evaluation of anticitrullinated filaggrin antibodies as hallmarks for the diagnosis of rheumatic diseases. Ann. Rheum. Dis.,63, 415-419.

Fathi, N.A.; Ezz-Eldin, A. M.; Mosad, E.; Bakry, R.M.; Hamed, H.B.; Ahmed, S.; Mahmoud, M.; Rashed, H.G.; Abdullah, F.(2008). Diagnostic performance and predictive value of rheumatoid factor, anti-cyclic-citrullinated peptide antibodies and HLA-DRB1 locus genes in rheumatoid arthritis. Int. Arch. Med.,1, 20.

Forslind, K.; Ahlmén, M.; Eberhardt, K.; Hafström, I.; Svensson, B. (2004). Prediction of radiological outcome in early rheumatoid arthritis in clinical practice: role of antibodies to citrullinated peptides (anti-CCP). Ann Rheum Dis. ,63, 1090-1095.

Hodkinson, B.; Meyer, P.W.; Musenge, E.; Ally, M.M.; Wadee, A.A.; Anderson, R.; Tikly, M. (2007). The diagnostic utility of the anti-CCP antibody test is no better than rheumatoid factor in south Africans with early rheumatoid arthritis. Clin. Rheumatol.,29(6), 615-618. 
Inanc, N.; Dalkilic, E.; Kamali, S.; Kasapoglu-Gunal, E.; Elbir, Y.; Direskeneli, H.; Inanc, M.(2007). Anti-CCP antibodies in rheumatoid arthritis and psoriatic arthritis. Clin. Rheumatol., 26, 17-23.

Kastbom, A.; Strandberg, G.; Lindroos, A.; Skogh, T.(2004). Anti-CCP antibody test predicts the disease course during 3 years in early rheumatoid arthritis (the Swedish TIRA project). Ann Rheum Dis., 63, 1085-1089.

Lee, DM.; Phillips, R.; Hagan, EM.; Chibnik, 1.B.; Costenbader, K.H.; Schur, P.H.(2009). Quantifying anti-CCP titer: clinical utility and association with tobacco exposure in patients with rheumatoid arthritis. Ann. Rheum. Dis.,68, 201-208.

Meyer, O.; Nicaise-Roland, P.; Santos, M.D.; Labarre, C.; Dougados, M.; Goupille, P.; Cantagrel, A.; Sibilia, J.; Combe, B. (2006). Serial determination of cyclic citrullinated peptide autoantibodies predicted five-year radiological outcomes in a prospective cohort of patients with early rheumatoid arthritis. Arthritis Res. Ther., 8(2), R40.

Miriovsky, B. J.; Michaud, K.; Thiele, G.M.; O'Dell, J.R.; Cannon, G.W.; Kerr, G.; Richards, J.S.; Johnson, D.; Caplan, L.; Reimold, A.; Hooker, R.; Mikuls, T.R. (2010). Anti-CCP antibody and rheumatoid factor concentrations predict greater disease activity in men with rheumatoid arthritis. Ann. Rheum. Dis., 69, 1292-1297.

Mobini, M.; Kashi, Z.; Mahdavi, M.R. (2010). The role of rheumatoid factor and anticyclic citrullinated peptide antibody in diagnosis of rheumatoid arthritis. IRCMJ., 12(2), 100-103.

Nell, V.P.; Machold, K.P.; Eberl, G.; Stamm, T.A.; Uffmann, M.; Smolen, J.S.(2004). Benefit of very early referral and very early therapy with disease-modifying antirheumatic drugs in patients with early rheumatoid arthritis. Rheumatol.,43, 906-914.

Ng, K.P.; Austın, P.; Ameratunga, K.; McQueen, F.(2006). Kole of ant1 cyclic citrullinated peptide 2 assay in longstanding rheumatoid arthritis. APLAR J Rheumatol., 9, 211 215.

Niewold, T.B.; Harrison, M.J.; Paget, S.A. (2007). Anti-CCP antibody testing as a diagnostic and prognostic tool in rheumatoid arthritis. Q. J. Med., 100, 193-201.

Rantapää-Dahlqvist, S.; de Jong, B.A.; Berglin, E.; Hallmans, G.; Wadell, G.; Stenlund, H.; Sundin, U.; van Venrooij, W.J. (2003). Anti-bodies against cyclic citrullinated peptide and IgA rheumatoid factor predict the development of rheumatoid arthritis. Arthritis Rheum., 48, 2741-2749.

Serdaroğlu, M.; Cakirbay, H.; Değer, O.; Cengiz, S.; Kul, S. (2008). The association of antiCCP antibodies with disease activity in rheumatoid arthritis. Rheumatol. Int., 28, 965-970.

Spadaro, A.; Riccieri, V. (2005). Methotrexate effect on anti-cyclic citrullinated peptide antibody levels in rheumatoid arthritis. Ann. Rheum. Dis., 64, 1241-1242.

Suzuki, K.; Sawada, T.; Murakami, A.; T Matsui, T.; Tohma, S.; Nakazono, K.; M Takemura, M.; Y Takasaki, Y.; T Mimori, T.; Yamamoto, K. (2003). High diagnostic performance of ELISA detection of antibodies to citrullinated antigens in rheumatoid arthritis. Scan. J. Rheumatol., 32, 197-204.

Tobon, G. J.; Youinou, P.; Saraux, A. (2010). The environment, geo-epidemiology, and autoimmune disease: Rheumatoid arthritis. Autoimmun. Rev., 9(5), 288-292. 
Tofiq, D.M. (2007). Diagnostic value of anti-cyclic citrullinated peptide 2 antibodies in comparison with IgM and IgA rheumatoid factors in rheumatoid arthritis, Fellowship of the Iraqi Commission for Medical Specialization. University of Baghdad, College of Medicine (abstract).

Vallbracht, I.; Rieber, J.; Oppermann, M.; Förger, F.; Siebert, U.; Helmke, K.(2004). Diagnostic and clinical value of anti-cyclic citrullinated peptide antibodies compared with rheumatoid factor isotypes in rheumatoid arthritis. Ann. Rheum. Dis., 63, 10791084.

Van Gaalen, F.A.; Visser, H.; Huizinga, T.W.J. (2005). A comparison of the diagnostic accuracy and prognostic value of the first and second anti-cyclic citrullinated peptides (CCP1 and CCP2) autoantibody tests for rheumatoid arthritis. Ann. Rheum. Dis., 64, 1510-1512.

Zeng, X.; Ai, M.; Tian, X.; Gan, X.; Shi, Y.; Song, Q.; Tang, F. (2003). Diagnostic value of anti-cyclic citrullinated peptide antibody in patients with rheumatoid arthritis. $J$. Rheumatol., 30, 1451-1455. 